\title{
How do Big Bang Disruptors look like? A Business Model perspective
}

\section{Daniel TRABUCCHI}

(corresponding author)

School of Management, Politecnico di Milano, Milano, Italy

Via Lambruschini, 4B 20156 Milano Italy

daniel.trabucchi@polimi.it

\author{
Luca TALENTI \\ School of Management, Politecnico di Milano, Milano, Italy \\ Via Lambruschini, 4B 20156 Milano Italy \\ luca.talenti@mail.polimi.it \\ Tommaso BUGANZA \\ School of Management, Politecnico di Milano, Milano, Italy \\ Via Lambruschini, 4B 20156 Milano Italy \\ tommaso.buganza@polimi.it
}


The breakthrough impact of new-born companies over the last years brought to the definition of Big Bang Disruption, a new kind of innovation that relies on an unencumbered development, an unconstrained growth, and an undisciplined strategy. The relevance from a practitioner perspective is straightforward: entire industries have been challenged and disrupted. From a theoretical perspective, the concept is less developed. This research aims to understand it through a Business Model perspective, better highlighting the design variables that may lead to this kind of innovation. Leveraging crisp-set Qualitative Comparative Analysis (csQCA) to define the necessary conditions to be called a Big Bang Disruptor, this paper relies on a rock clustering method - using the Unicorns' list as the sample - to highlight common patterns. Results show two main factors: the chance to innovate the meaning and to rely on a two-sided market structure as key variables to design a Big Bang Disruptor. Results are discussed under the lenses of previous research. Finally, limitations and avenues for further studies are explored.

Keywords: Big Bang Disruption; Business Model; Two-Sided Market; Innovation of Meaning; Unicorns 


\section{Introduction}

Over the last years, the concept of Big Bang Disruption has drawn attention both from scholars and practitioners. The publication of "Big Bang Disruption" by Downes and Nunes (2014) sheds light on an emerging phenomenon that is challenging several mature industries: the rise and the disruptive impact of new-born companies that in a very short time can change the market equilibrium.

According to the authors, Big Bang Disruptors (BBDs) rely on an unencumbered development, unconstrained growth, and undisciplined strategy, making their impact devastating for incumbents on the market. Moreover, they seem able to challenge traditional management models and theories significantly.

First, the concept of Big Bang Disruption challenges and somehow enlarges its reference theory: the disruptive innovation model by Christensen (Christensen, 1997). The original model claims that there are technologies that at the very beginning of their development process may be underperforming even for the lowest-end of the market, but, investing on them, they may go through a slow process that bring them to overcome even the needs required at the highest-end of the market (e.g., Bower and Christensen, 1995; Christensen, 1997). Nevertheless, Downes and Nunes present cases of "disruptive innovations" that shrink the slow process described by Christensen. This perspective seems coherent with the critiques that have been moved to the disruptive innovation model (Christensen et al., 2015). Second, BBDs are claimed to have an "unconstrained growth", which challenges the traditional and established model for the diffusion of innovation (Rogers, 2010). Rogers described the common path of diffusion and acceptance of innovation, highlighting five different segments of customers that adopt the product over time. The original model shows how innovations gain popularity segment after segment. Downes and Nunes proposed their revised version of the model through the "Shark-Fin" diffusion curve. Disrupters face just two market segments: trial users and the vast majority, going quickly through all the diffusion process.

Finally, the model proposed by Treacy and Wiersema (1995) defines three main value disciplines that market leaders should choose: operational excellence, product leadership, and customer intimacy building on the Porter's (1980) strategy model that claims for 
differentiation, cost leadership or a niche strategy. Big Bang Disruptors challenge these models being - at the same time - cheaper, better and closer to the customers.

These three points show how the cases presented by Downes and Nunes can challenge years of management research, proposing cases which are not fitting in traditional models.

The practitioner relevance of their work is straightforward: BBDs can have a significant impact on the market, both regarding customer base and concerning investments. On the one hand, entrepreneurs would desire to leverage the benefits proper of disruption and, on the other hand, incumbents aim at being able to face them effectively.

From the academic perspective, many emphases has been given to the concept of disruptive innovation mainly taking a technological perspective (e.g., Christensen, 1997; Kostoff et al., 2004; Sainio and Puumalainen, 2007; Kilkki et al., 2018). Given the novelty of the broader concept of Big Bang Disruption, little research - mainly as conference proceedings - has been done on the phenomenon (e.g., Karimi \& Walter, 2015; Kazan et al., 2014; Kobus, 2016; Smailhodzic, Boonstra, \& Langley, 2016), however, on the other hand, a concept which can challenge at least three fundamental management pillars in a row needs scholarly attention. This research aims to understand the commonalities behind innovation which has an unencumbered development, an unconstrained growth, and an undisciplined strategy. In other words, this paper digs in BBDs to define common patterns concerning their Business Model configuration. The concept of Business Model received an increasing attention over the last years, both as a tool to describe a company (e.g., Osterwalder and Pigneur, 2010) and as a unit of analysis (e.g., Amit and Zott, 2001; Zott et al., 2011; Massa et al., 2017; Battistella et al., 2017). Therefore, this research aims to understand which are the design variables of the business model that may lead to the creation of a BBD.

\section{Theoretical Background}

\subsection{Business Model Design}

The concept of business model has been highly studied in recent years, and different scholars proposed significantly different perspectives. Among the others, Stewart and Zhaon (2000) consider the business model as a statement, Applegate (2001) as a description, Afuah and Tucci (2001) as a method, while Osterwalder and Pigneur (2010) as a conceptual tool and Amit and Zott (2000) a suitable unit of analysis for e-businesses. In many other cases, the business 
model has been studied without providing an explicit definition (Zott et al., 2011). Despite the lack of a commonly accepted definition, since mid-90s researchers have studied this concept, especially with the rise of the Internet and e-business (Amit and Zott, 2001).

The business model can be used to explain the value creation process and the firm's competitive advantages. According to Hamel and Ruben (2000), to survive in the competitive market, companies need to develop new business models. Business models themselves can become a competitive advantage (Chirstensen, 2001; Casadesus-Masanell and Ricart, 2010), having a direct impact on financial performances (Kulins et al., 2016). Indeed, researchers show how the design of an appropriate business model may be the key to unlock the potential value embedded in innovation (e.g., Chesbrough and Roenbloom, 2002; Björkdahl, 2009). In particular, it gets together the concepts of value creation, and value capturing that are by definition both part of an innovation (e.g., Teece, 1986) even if it may be challenging to implement both of them (e.g., Mizik and Jacobson, 2003; Doganova and Eyquem-Renault, 2009). Furthermore, firms can see the business model itself as a subject of innovation (Mitchell and Coles, 2003). Indeed, even it is a recent stream in the literature (Trimi and Berbegal-Mirabent, 2012; Ghezzi et al., 2013; Ghezzi et al., 2015), scholars are paying growing attention to the concepts of Business Model Innovation and Business Model Design, described as the managerial intent to reconfigure the firm's existing business model or to create a new one (e.g., Massa et al., 2017; Foss and Saebi, 2017). In particular, Business Model Design generally investigates the representation of business models, for example through ontologies (Zott and Amit, 2007; Pigneur and Werthner, 2009; Zott and Amit, 2010). The Business Model Canvas (Osterwalder and Pigneur, 2010) represents one of the main developments in Business Model Design, being widely adopted both by practitioners and academics (e.g., Chesbrough, 2010). In this perspective, recent literature also focused on the role of the manager behind the business model design process, highlighting the cognitive process at its foundations (Schneckenberg et al., 2018).

In this complex scenario, where different dimensions and perspectives have been considered (Rayna and Striukova, 2016; Massa et al., 2017; Foss and Saebi,2017; Ghezzi and Cavallo, 2018; Schneckenberg et al., 2018), this paper considers the business model as a conceptual tool to describe the firm (Osterwalder and Pigneur, 2010).

This lead to the definition of the research question of this paper. Bringing together the concept of Big Bang Disruption and Business Model: are there common patterns in the 
business models of Big Bang Disruptors? In other words, are there commonalities among the design variables of the business models implemented by BBDs?

To answer the research question, a conceptual framework is going to be built, relying on previous literature to define the main alternatives and concepts regarding the design variables of the different building blocks composing a business model.

\subsection{Developing a Conceptual Framework}

The Business Model Canvas presented by Osterwalder and Pigneur (2010) has often been used as a tool to describe companies even in academic researches (e.g., Adrodegari et al., 2017; Daly, 2017; Bertels et al., 2015; Toro-Jarrín et al. 2016), mainly to analyze and compare case studies. Nevertheless, this tool has often been criticized (e.g., Cosenz, 2017) and several other canvases have been proposed. Among the others, the Value Proposition Canvas by Osterwalder et al. (2014) or the Lean Canvas (Maurya, 2012). In particular, the Lean Canvas aims to be suitable for entrepreneurs and fast-growing companies, while the original canvas seems to be better for established companies (Maurya, 2012).

This research aims to search for common patterns among the design variables of the business model among the BBDs; therefore, we are not considering industry-related characteristics (e.g., the key activities or the key resources that would be pointed out by the Business Model Canvas) or company-specific dimension (such as the solution offered to the market, according to the Lean Canvas). Indeed, we build on the canvases mentioned above to create the necessary building blocks to propose the conceptual framework at the basis of this research. Therefore, a literature survey for each design variable is going to be presented, highlighting the constructs used to proceed with our investigation. These components are the structural elements of a business, or the so-called antecedents (Herrmann et al., 2007; Rumble \& Mangematin, 2015; Storey et al., 2016). The upcoming dimensions are going to represent the basis on which we are going to build our research on.

Relying on previously developed models, six building blocks have been considered: i) the innovation strategy, referring to the way in which the solution is designed to resolve the highlighted problem (referring to the Lean Canvas building blocks), ii) the value proposition, iii) the channels, iv) the customer relationship, v) the cost structure and vi) the revenue 
streams. Each of the building blocks is going to be further explored, highlighting the constructs emerging from the literature.

\subsubsection{Innovation strategy}

Verganti (2009) proposes a model summarizing three main innovation strategies: technologypush innovation, market-pull innovation, and design-driven innovation. The presented frameworks leverage on previous academic studies on the dyadic relationship between technology and market needs in innovation, adding a third perspective: the meaning, the reason why people would use a product or a service. The three strategies have deep roots in the scientific literature. Technology is considered one of the leading innovation triggers, often bringing to breakthrough innovations (e.g., Anderson and Tushman, 1990; Christensen, 1997; Schuelke-Leech, 2018). Market needs have been highly studied, giving birth to solutions that provide a clear answer to what customers are searching (e.g., Von Hippel 1986). Finally, the meaning, the reason why being a product or a service, may bring to breakthrough innovation by shifting the paradigm in the market (e.g., Verganti, 2008; Buganza et al., 2015; Dell'Era et al.,2017; Magistretti and Dell’Era, 2018).

\subsubsection{Value Proposition}

The academic literature identifies three main types of value proposition: cost leadership, premium product and ease of use. The first two are among the traditional strategies proposed by Porter (1980), focusing on the chance to provide a product with a price lower than competitors, or a very high-quality product. The other one is coherent with the evolution of market expectations over the last decades. Ease of use is related to quick and easy access to product or service (Treacy, 2005; Treacy \& Wiersema, 1997).

\subsubsection{Channels}

The first categorization of channels is the division between digital and physical channels (Downes et al., 2000). A physical channel may be direct or indirect (e.g., Ostwerwalder and Pigneur, 2010), while a digital channel may be outsourced digital (e.g., marketplaces), proprietary digital (e.g., proprietary marketplaces) and applications. While the latter is mobile-based, the two first channels are internet platforms. 


\subsubsection{Customer Relationship}

Leveraging the insights of different studies (e.g., Osterwalder et al., 2010; Hagiu, 2009; Bhradwaj et al., 2013), it is possible to highlight three main strategies related to the customer relationship. First, the chance to address a single market segment. Second, the chance to address multiple segments. Finally, the chance to rely on a multi-sided structure, bringing together different segment through an intermediary platform. Multi-sided platforms that in the literature have also been addressed two-sided market, are intermediaries that bring together different kinds of customers that have some sort of relations among them (Rochet and Tirole, 2003; Muzellec et al., 2015; Trabucchi and Buganza, 2018; Tauscher and Laudien, 2018). In particular, they are different from the "multiple segments" because the different sides are groups of customers that interact among them on the same product value chain, while multiple segments are not necessarily interdependent among each other.

Traditionally, a niche market has been considered a type of customer relationship, which is becoming less and less relevant due to the diffusion of digital technologies (Bhradwaj et al., 2013).

\subsubsection{Cost Structure}

Costs are classified in different ways to their nature and their sources, but they coexist within the same company. Digital technologies enabled, over the last decades, a radical revolution in the cost structure of companies. Several digital businesses are based on aa zero-marginalcost structures that can be opposed to a more traditional (brick-and-mortar base) non-zero marginal cost structure (Rifkin, 2014). The first one allows a rapid scale up and a potential global impact since the beginning; it is common in software-based industries and digital services (Rifkin, 2014).

\subsubsection{Revenue Streams}

Two main types of revenues may be identified: a direct purchase or a subscription-based purchase (Osterwalder and Pigneur, 2010). Further developments in the digital business models brought to a broader classification: advertisement, freemium, in-app selling or pay- 
per-usage (e.g., Buganza et al., 2015; Maurya, 2012; Osterwalder and Pigneur, 2010; Trabucchi et al., 2017a).

Table 1 summarizes the fundamental constructs and the key references for each building block.

\begin{tabular}{|c|c|c|}
\hline Building Block & Constructs & References \\
\hline Innovation strategy & $\begin{array}{l}\text { Design-Driven } \\
\text { Technology-Push } \\
\text { Market-Pull }\end{array}$ & $\begin{array}{l}\text { Von Hippel, } 1986 \\
\text { Anderson and Tushman, } 1990 \\
\text { Verganti, } 2009\end{array}$ \\
\hline Value Proposition & $\begin{array}{l}\text { Cost Leadership } \\
\text { Premium Product } \\
\text { Ease of use }\end{array}$ & $\begin{array}{l}\text { Porter, } 1980 \\
\text { Treacy, } 2005 \\
\text { Treacy \& Wiersema, } 1997\end{array}$ \\
\hline Channels & $\begin{array}{l}\text { Physical channels } \\
\text { Mobile applications } \\
\text { Proprietary digital channels } \\
\text { Outsources digital channels }\end{array}$ & $\begin{array}{l}\text { Downes and Mui, } 2000 \\
\text { Osterwalder and Pigneur, } 2010\end{array}$ \\
\hline Customer Relationship & $\begin{array}{l}\text { Single Segment } \\
\text { Multiple Segment } \\
\text { Multi-Sided Markets }\end{array}$ & $\begin{array}{l}\text { Hagiu, } 2009 \\
\text { Osterwalder and Pigneur, } 2010 \\
\text { Bharadwaj et al., 2013 } \\
\text { Rochet and Tirole, 2003; Muzellec et al., } \\
\text { 2015; Tauscher and Laudien, 2018; } \\
\text { Trabucchi and Buganza, } 2018\end{array}$ \\
\hline Cost Structure & Zero or Not-Zero Marginal cost structure & Rifkin, 2015 \\
\hline Revenue Streams & $\begin{array}{l}\text { Freemium } \\
\text { In-app selling } \\
\text { Advertisement } \\
\text { Pay per usage } \\
\text { Purchase } \\
\text { Subscription }\end{array}$ & $\begin{array}{l}\text { Osterwalder and Pigneur, } 2010 \\
\text { Buganza et al., } 2015 \\
\text { Trabucchi et al., 2017a }\end{array}$ \\
\hline
\end{tabular}

Table 1 - Conceptual framework

\section{Research Design and Method}

To reach the goal of this research, understanding which are the business model features of a Big Bang Disruption, a two-step process has been designed (summarized in Figure 1).

In the first step, a way to identify BBDs needs to be defined. In the second step, a business model analysis of the sample has to be performed.

First of all, since the only sample of Big Bang Disruptors is the one present in the seminal book previously mentioned (Downes and Nunes, 2004), a preliminary analysis through a Qualitative Comparative Analysis (QCA) is performed, to define necessary conditions a case must fulfill to be classified as BBD.

Then, relying on the results of the previous step, a new sample - based on the Unicorns' list - has been classified according to the rules emerged from the QCA. Following, a clustering analysis is performed, aiming to define common patterns in the business model design of this 
kind of innovations. In the next sub-section, the entire research process is going to be fully described.

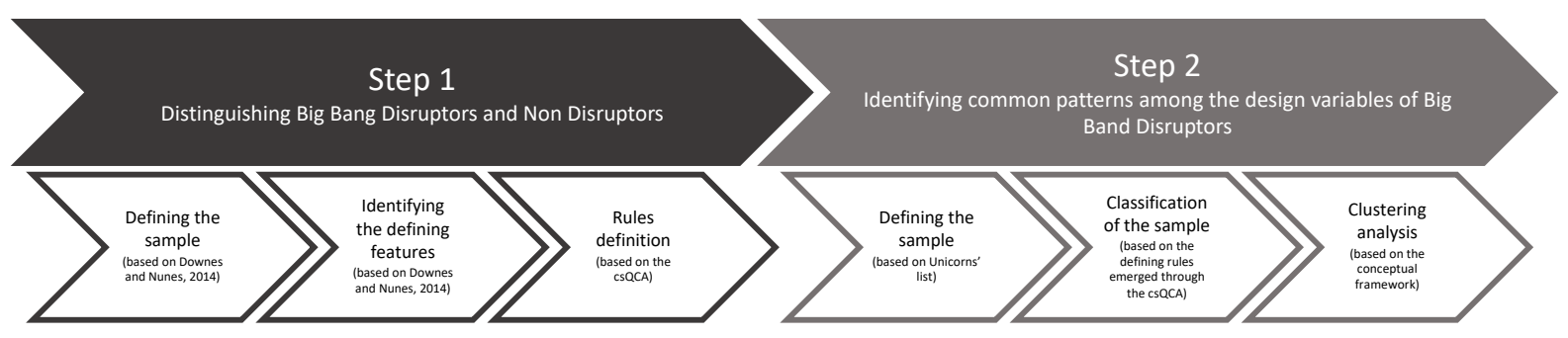

Figure 1 - Research process

\subsection{Step 1: Distinguishing Big Bang Disruptors and Non-Disruptors}

For the preliminary analysis of this study, the crisp-set qualitative comparative analysis (QCA) is selected. QCA is a research method which enables the inference of typical configurations within a limited set of cases (or observations) (Ganter and Hecker, 2014). In the crisp-set Qualitative Comparative Analysis (csQCA), the features according to which the cases are evaluated are binary, where 1 implies full membership to the condition while 0 implies no membership. The algorithm tries to infer the combinations of conditions which lead to the outcome by constructing a Boolean table, also called truth table, where all the possible combinations are present (a total of $2^{k}$ combination, where $k$ is the number of conditions). Two parameters characterize the QCA: i) consistency, that measures the degree to which a causal relationship between a condition configuration and the outcome is met (Ragin, 2006, 2013); and ii) coverage: that measures "the size of the overlap of two sets relative to the size of the larger set" (Ragin, 2006). The csQCA allows distinguishing between sufficient and necessary conditions for the explanation of the Boolean outcome.

The training set of the algorithm has been defined by relying on the 23 disruptors presented by Downes and Nunes (2014) in their book, which have been grouped into nine industries (see Table 2). To define the association rules that define a Big Bang Disruptors, a control set of Not-Disruptors (NDs) is needed. Therefore, 17 companies have been identified neglecting the definition of $\mathrm{BBD}$, considering companies that act as followers or imitators without getting the fast and pervasive diffusion of BBDs (see Table 2). For the sake of clarity, the companies have been identified aiming to deny the basic definition of BBD (at least one of the three characteristics: undisciplined strategy, unconstrained growth, and unencumbered development). Starting from the companies mentioned in the book, such as Spotify, the 
authors identified other companies that do not have those characteristics, for example Tidal, which followed Spotify without having an unconstrained growth or proposing radical differences from the predecessor.

\begin{tabular}{|c|c|c|}
\hline $\begin{array}{l}\text { Big Bang } \\
\text { Disruptors }\end{array}$ & Non-Disruptors & Industry \\
\hline $\begin{array}{l}\text { Jawbone } \\
\text { AppleiPodd }\end{array}$ & $\begin{array}{c}\text { Google Glass, } \\
\text { PebbleWatch } \\
\text { Pirate3D }\end{array}$ & Hardware \\
\hline $\begin{array}{c}\text { AirBnb } \\
\text { Wimdu } \\
\text { Hailu } \\
\text { Lyft } \\
\text { Uber }\end{array}$ & $\begin{array}{l}\text { Housetrip } \\
\text { Karhoo } \\
\text { Leap Transit }\end{array}$ & On demand/Intermediaries \\
\hline $\begin{array}{l}\text { Twitter } \\
\text { Reddit }\end{array}$ & Google+ & Social \\
\hline $\begin{array}{c}\text { TripAdvisor } \\
\text { Yelp }\end{array}$ & Quirky & Business Rating \& Advertising \\
\hline Skype & $\begin{array}{l}\text { Joost, } \\
\text { iMessage }\end{array}$ & Communication/Mobile Software \\
\hline $\begin{array}{l}\text { Prosper } \\
\text { Lending Club }\end{array}$ & Clinkle & Fintech \\
\hline $\begin{array}{c}\text { eBay } \\
\text { Amazon }\end{array}$ & Dot\&Bo & e-Commerce \\
\hline $\begin{array}{l}\text { Netflix } \\
\text { Hulu } \\
\text { Youtube }\end{array}$ & $\begin{array}{c}\text { Nouncer } \\
\text { Rdio }\end{array}$ & Media \\
\hline $\begin{array}{l}\text { Spotify } \\
\text { DropBox } \\
\text { Zynga } \\
\text { Google }\end{array}$ & $\begin{array}{c}\text { Zune } \\
\text { AppSumo } \\
\text { Tidal }\end{array}$ & Internet Software \& Services \\
\hline
\end{tabular}

The final set of forty companies (BBDs + NDs) is evaluated according to 9 different conditions, or binary features, as found in Downes and Nunes (2014). The set of features (defined through an in-depth analysis of the book) is presented in Table 3, starting from the three fundamentals of Big Bang Disruption. The conditions are then assessed for each company through secondary sources of information. The assessment has been done independently by two of the three authors, further considerations have been done when the data gathering brought to different results.

The qualitative comparative analysis has been performed through to the R package "QCA". It allows the usage of a graphic user interface (GUI) (Duşa, 2007) and the performance of both csQCA and fuzzy set QCA. Given the reduced number of instances in the dataset, it is established a frequency threshold of one case and a consistency of $75 \%$ coherently with previous researches (e.g., Schneider \& Wagemann, 2010). 


\begin{tabular}{|c|c|c|}
\hline $\begin{array}{l}\text { Big Bang Disruption } \\
\text { Characteristic }\end{array}$ & Condition & Rationale of condition \\
\hline \multirow{3}{*}{$\begin{array}{l}\text { Unencumbered } \\
\text { Development }\end{array}$} & $\begin{array}{l}\text { Exponential } \\
\text { Technology in Use }\end{array}$ & $\begin{array}{l}\text { The potential of disruptors is enclosed in exponentially improving } \\
\text { technologies(Kurzweil, 2005) }\end{array}$ \\
\hline & $\begin{array}{l}\text { Existence of Direct } \\
\text { Network } \\
\text { Externalities }\end{array}$ & $\begin{array}{l}\text { The increase in the number of users leads to a more than proportional } \\
\text { increase in the value of the network (Hellofs \& Jacobson, 1999; Libert et al., } \\
\text { 2016) }\end{array}$ \\
\hline & $\begin{array}{l}\text { Strong Intellectual } \\
\text { Property Protection }\end{array}$ & $\begin{array}{l}\text { To make the development process faster and cheaper, disruptors should } \\
\text { rely on off-the-shelf components,i.e.,. characterized by low intellectual } \\
\text { property protection (Bontis, 2001) }\end{array}$ \\
\hline \multirow[t]{2}{*}{ Undisciplined Strategy } & $\begin{array}{l}\text { No Classical Porter } \\
\text { Positioning }\end{array}$ & $\begin{array}{l}\text { Disruptors do not follow any of Porter's generic strategies but an optimized } \\
\text { combination of them (Kim et al., 2004; Miller, 1988; Porter, 1980, 2001) }\end{array}$ \\
\hline & $\begin{array}{l}\text { Customization in } \\
\text { Place }\end{array}$ & $\begin{array}{l}\text { The solution provided by the disruptor is not only better and cheaper but } \\
\text { also more customized (Nielsen \& Brunoe, 2014) }\end{array}$ \\
\hline \multirow[t]{4}{*}{ Unconstrained Growth } & $\begin{array}{l}\text { Lowered } \\
\text { Transaction Costs }\end{array}$ & $\begin{array}{l}\text { Disruptors, thanks to digitalization, lead to a decrease in searching, } \\
\text { information and access costs (Madhok, 2002) }\end{array}$ \\
\hline & $\begin{array}{l}\text { Negligible Switching } \\
\text { Costs }\end{array}$ & $\begin{array}{l}\text { The adoption of the disruptive solution is pervasive and so simple to adopt } \\
\text { that it does not follow the classical Roger's diffusion of innovation (Katz \& } \\
\text { Shapiro, 1985) }\end{array}$ \\
\hline & $\begin{array}{l}\text { No Customer } \\
\text { Segmentation }\end{array}$ & $\begin{array}{l}\text { The disruptor is able to target everybody since the beginning since the } \\
\text { solution is customizing (Fleisher \& Bensoussan, 2003) }\end{array}$ \\
\hline & $\begin{array}{l}\text { No Marginal Cost of } \\
\text { Production }\end{array}$ & $\begin{array}{l}\text { The company is able to scale up, and scale down, incurring in little to no } \\
\text { additional cost (Rifkin, 2014) }\end{array}$ \\
\hline
\end{tabular}

Table 3 - Step 1: Set of features used to define a Big Bang Disruptors through the csQCA

The analysis brought to the definition of four necessary - but not sufficient - conditions to be defined as a BBD. Any disruptor with a Big Bang effect must satisfy these conditions: i) usage of an exponential technology, ii) absence of a classical Porter strategy, iii) absence or irrelevance switching costs, and iv) absence of customer segmentation. Each rule is then characterized by three to five non-necessary conditions as presented in Table 4 . The table is not presenting all the possible combinations that have been considered by the algorithm during the analysis, but only the ones relevant to classify an observation among BBDs and NDs. The set of necessary and non-necessary conditions - getting to one of the four rules form a sufficient condition for being considered a BBD.

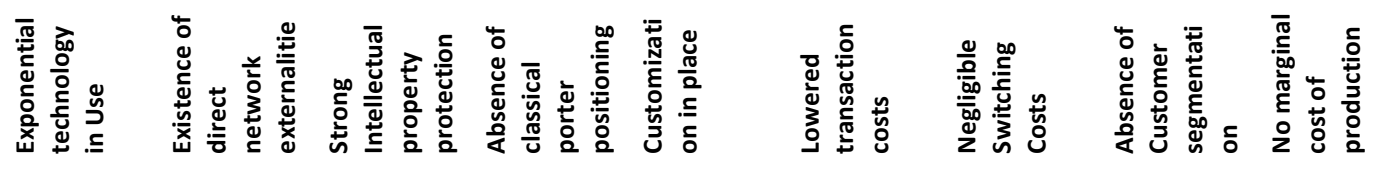

\begin{tabular}{|l|l|l|l|l|l|l|l|l|l|}
\hline Rule 1 & $1^{*}$ & - & 0 & $1^{*}$ & - & 1 & $1^{*}$ & $1^{*}$ & 1 \\
\hline Rule 2 & $1^{*}$ & 1 & - & $1^{*}$ & 0 & 1 & $1^{*}$ & $1^{*}$ & 1 \\
\hline Rule 3 & $1^{*}$ & 0 & 0 & $1^{*}$ & 1 & - & $1^{*}$ & $1^{*}$ & 1 \\
\hline Rule 4 & $1^{*}$ & 0 & 1 & $1^{*}$ & 1 & 0 & $1^{*}$ & $1^{*}$ & 0 \\
\hline
\end{tabular}

Table 4 - Defining rules. 1 implies the fulfillment of the condition, 0 implies the absence of the condition, - implies the irrelevance of the condition in the rule (may be both 1 or 0 ), ${ }^{*}$ indicates the necessary conditions. For a rule to be satisfied, the series of condition reported in each line has to be fulfilled. 


\subsection{Step 2: Identifying common patterns among the design variables of Big Bang Disruptors}

\subsubsection{Defining the sample}

The purpose of this study is the definition of the Business Model characteristics which distinguish a Big Bang Disruptors. In order to reach the aim, a recognized sample of companies where both BBDs and NDs is needed. The Unicorn list (private companies with a minimum market evaluation of \$1 billion), updated in March 2017 and available at Cbinsights.com, has been used. It has been selected since i) It is a widely acknowledged set of companies by both professionals and academics (e.g., De Massis et al., 2016; Hathaway, 2016); ii) it contains a large number of fast-growing companies so that we can assume the presence of a relevant subset of disruptors (De Massis et al., 2016; Downes \& Nunes, 2014); iii) it is characterized by heterogeneity of industries (more than thirty) and countries (more than twenty) (CB Insights, 2016), aiming to increase the generalizability of the results according to these dimensions. Finally, it is important to highlight how these companies share a private capitalization higher than $\$ 1$ billion, which is linked with a relevant market success that leads to that evaluation (e.g., De Massis et al., 2016). The dataset is composed of a total of 186 companies.

First, the dataset has been analyzed according to the nine binary conditions identified in the preliminary analysis with the same logic previously exposed. Therefore, the set has been divided into BBDs and NDs through the four association rules. Out of the 186 unicorns, the association rules determine $79 \mathrm{BBDs}$, corresponding to $42.5 \%$ of the instances, as reported in Table 5.

Big Bang Disruptors

Non Disruptors

\begin{tabular}{|c|c|c|c|}
\hline 23andMe & One97 Communications & Actifio & MarkLogic \\
\hline 51Xinyongka & Pinterest & Adaptive Biotechnologies & Medallia \\
\hline Adyen & Prosper Marketplace & Africa Internet Group & Meizu Technology \\
\hline Airbnb & Quanergy Systems & Age of Learning & Mia.com \\
\hline Apus Group & Rong360 & Anaplan & MindMaze \\
\hline Automattic & Shazam & AppDirect & Moderna \\
\hline Avant & Shopclues & Appnexus & Mofang Gongyu \\
\hline AVAST Software & Slack Technologies & Apttus & MongoDB \\
\hline BlaBlaCar & Snapdeal & Auto1 Group & Mu Sigma \\
\hline Careem Networks & Souq & BeiBei & Nextdoor \\
\hline China Rapid Finance & Spotify & benevolent.ai & NIO \\
\hline Compass & Stripe & Bloom Energy & Okta \\
\hline ContextLogic (dba. Wish) & SurveyMonkey & Blue Apron & OpenDoor Labs \\
\hline Coupang & TangoMe & Buzzfeed & Oscar Health Insurance Co. \\
\hline Credit Karma & Thumbtack & C3 loT & $\mathrm{OVH}$ \\
\hline Dada & TransferWise & Carbon3D & Nanopore \\
\hline Decolar & Uber & China Internet Plus Holding & Technologies \\
\hline Delivery Hero & VANCL & CJ Games & Palantir Technologies \\
\hline Didi Chuxing & Weiying & Cloudera & Panshi \\
\hline DocuSign & Yello Mobile & CloudFlare & Pivotal \\
\hline Dropbox & Yixia & CureVac & Pluralsight \\
\hline
\end{tabular}




\begin{tabular}{|c|c|c|c|}
\hline Ele.me & Zhangyue & Cylance & Procore Technologies \\
\hline Eventbrite & Zhihu & Datto & Promasidor Holdings \\
\hline Fanli & Zocdoc & DJI Innovations & Proteus Digital Health \\
\hline Flipkart & Zomato Media & Docker & Qualtrics \\
\hline Funding Circle & & Domo Technologies & Razer \\
\hline Github & & DraftKings & ReNew Power Ventures \\
\hline Glassdoor & & Fanatics & Royole Corporation \\
\hline Global Fashion Group & & Fanduel & SMS Assist \\
\hline Go-Jek & & Farfetch & Social Finance \\
\hline GrabTaxi & & Flatiron Health & SpaceX \\
\hline GuaHao & & Garena & Sprinklr \\
\hline Gusto & & Global Switch & STX Entertainment \\
\hline Hike & & Greensky & Tanium \\
\hline Houzz & & Guazi & Ten-X \\
\hline Human Longevity & & Hellofresh & The Honest Company \\
\hline iCarbonX & & Huimin & Trendy Group International \\
\hline Illumio & & Huochebang & Tujia \\
\hline Instacart & & Infinidat & UBTECH Robotics \\
\hline iwjw.com & & Infor & Unity Technologies \\
\hline Jawbone & & InMobi & Uptake \\
\hline Kabbage & & Insidesales.com & URWork \\
\hline Kik Interactive & & Intarcia Therapeutics & Vice Media \\
\hline Klarna & & ironSource & Vox Media \\
\hline LaKala & & iTutorGroup & Warby Parker \\
\hline Lookout & & JetSmarter & WeWork \\
\hline Lu.com & & Jiuxian & Xiaohongshu \\
\hline Lyft & & JustFab & Xiaomi \\
\hline Mercari & & Kendra Scott Jewelry & Zenefits \\
\hline Mogujie & & Koudai Gouwu & Zeta Interactive \\
\hline Mozido & & Lianjia & Zhong An Insurance \\
\hline OfferUp & & Liepin & Zoom Communications \\
\hline Ofo & & LIfeMiles & Zoox \\
\hline Olacabs & & Magic Leap & Zscaler \\
\hline
\end{tabular}

Table 5 - List of BBDs and NDs according to the application of the rules

\subsubsection{Data Gathering}

Consequently, to the classification of the Unicorns between BBDs and NDs, they have been evaluated according to the six building blocks defined in the conceptual framework.

The creation of the database, analyzing each of the 186 companies through the conceptual framework previously presented, has been done independently by two of the authors and later compared to increase the validity of the judgment. Each design variable of each building block has been evaluated through a binary variable (1 presence, 0 absence) relying on secondary sources (e.g., official website, digital magazines). The entire dataset is then composed of a $186 \times 20$ Boolean table, which is available upon request to foster other studies on the same variables.

To increase the reliability of the built database, it has been further tested through a panel of experts. Three external experts - chosen within the academic community for their knowledge of Business Model, Big Bang Disruption and innovation management - evaluated a random subset of the database independently. Two different experts have analyzed each tested 
company through a survey based on the conceptual model. The results are then compared with the performed classification, showing a consistency rate off response higher than $80 \%$ which leads to the acceptance of the database.

\subsubsection{Data Analysis}

The formation of homogeneous groups of BBDs and NDs is performed with a robust clustering of categorical attributes (ROCK). The ROCK is an unsupervised statistical method specific for the case of binary variables, where most of the clustering algorithm are not suited for (Muhlenbach \& Lallich, 2009). The ROCK requires two inputs: i) beta, which sets the minimum percentage of common features two companies should share to be considered neighbors, or belonging to the same cluster; and ii) theta, which sets the minimum percentage of links between two clusters' instances, out of the potential number of links, for the two clusters to be merged.

Different levels of beta and theta have been tested, due to the trade-off between the number of clusters and their homogeneity (Hastie et al., 2009). Through an iterative approach on both the parameters, we finally identified two clusters for the BBDs dataset (beta equal to 0.9 and theta equal to 0.01 ) and three clusters for the NDs (beta equal to 0.95 and theta equal to 0.01). It shall be noticed that both parameters assume similar values in the two analyses and are significant of loose constraints (Dutta et al., 2005). A very low similarity coefficient is required for two instances to be considered as neighbors, due to the high number of attributes compared to the number of samples in each dataset, a tighter constraint would lead to the definition of a sharply increasing number of clusters (Guha et al., 2000).

Finally, the over-population or under-population of certain conditions in the formed clusters is measured with the lift measure. The lift score is the ratio of the frequency of a specific feature inside the cluster and the frequency of the same feature in the overall population. If the lift is higher than 1 , the cluster is overpopulated by that feature, if lower than one the cluster is underpopulated by the feature under analysis (Tuffery, 2011). To test the statistical significance of the over or under population, we rely on the binomial test and the corresponding p-value (e.g., Maidique and Zirger, 1984; Taddesse and Belay, 2004).

The ROCK method has been performed thanks to the rock cluster function implemented in the R package CBA (Clustering for Business Analytics). 


\section{Results}

Data show a good heterogeneity concerning industries among all the clusters, having several industries which are represented in both BBDs NDs' clusters (such as Hardware or Cybersecurity). At the same time, some commonalities can be found. For example, in the first BBD cluster many companies belonging to Fintech (e.g., Credit Karma, Avant), Internet software and services (e.g., Slack Technologies, Automattic), and social platforms (e.g., Hike, Zomato Media) are present, while in the second there is a relatively higher concentration of marketplaces (e.g., Airbnb, Uber, BlaBlaCar), coherently with their core characteristics. Similarly, in the NDs clusters we can find some industries which are more coherent with the general traits, having other marketplaces in the e-Shopper cluster (e.g., The Honest Company, BeiBei, Mia.com), a lot of Big Data (e.g., Domo Technologies, Cloudera) and Fintech (e.g., Social Finance, Zhong An Insurance) companies in the Digital Tailors, and may hardtechnology industries in the Inventors' cluster (e.g., Magic Leap, ReNew Power Ventures, Zoox, UBITECH Robotics, DJI).

Figure 2 shows descriptive analyses of the five clusters emerging from the data analysis.
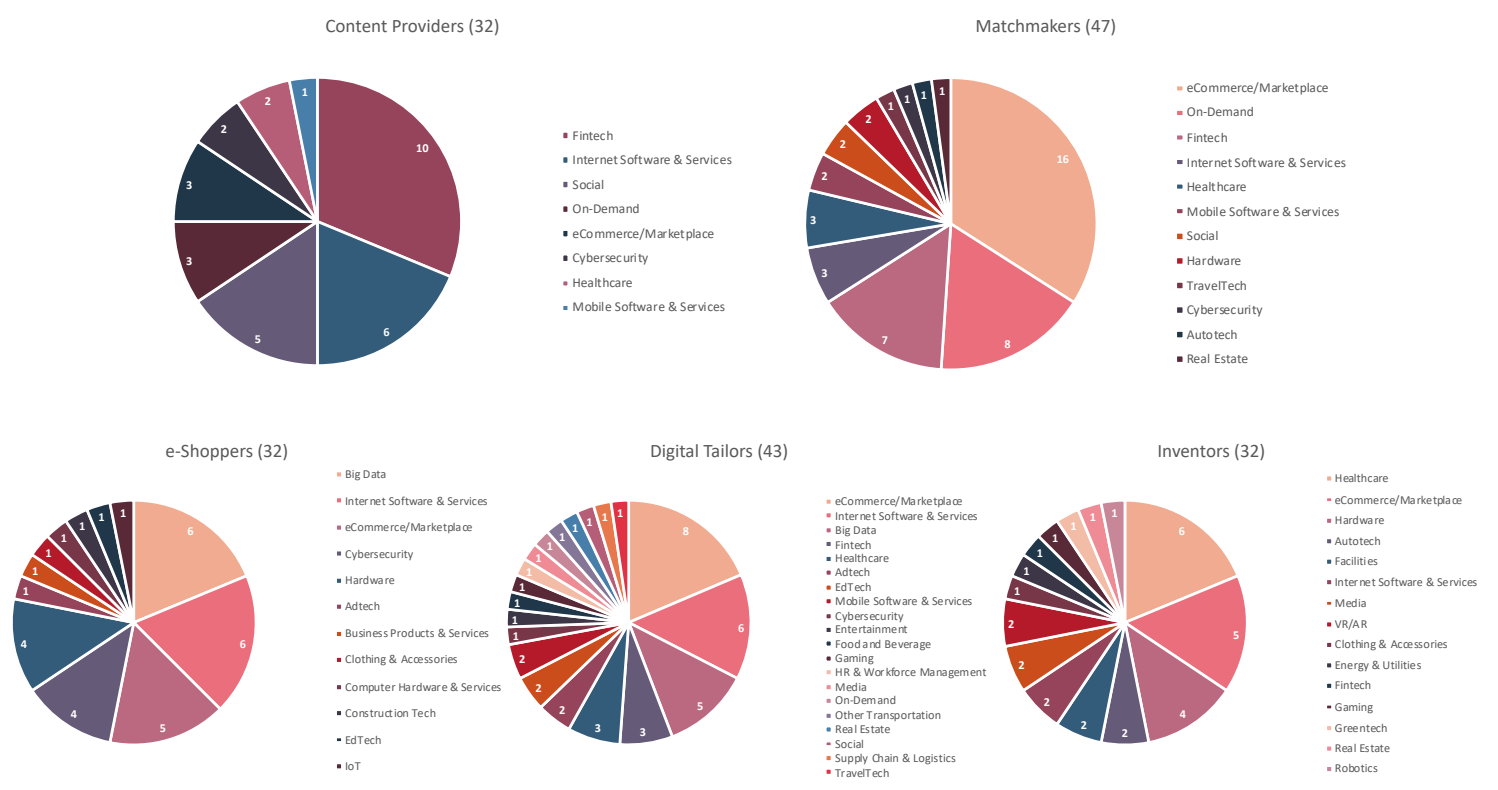

Figure 2 - Descriptive analysis of the clusters

Moving from a general description to a more in-depth analysis, Table 6 shows the distribution of the design variables identified in the conceptual framework in the different clusters. The stars show the degree of statistical significance of the over-population (higher than 1) or under-population (lower than 1) of the feature in the cluster calculated through an exact 
binomial test. Moreover, the table shows the degree of over- or under-population in the cluster in terms of lift measure and its significance.

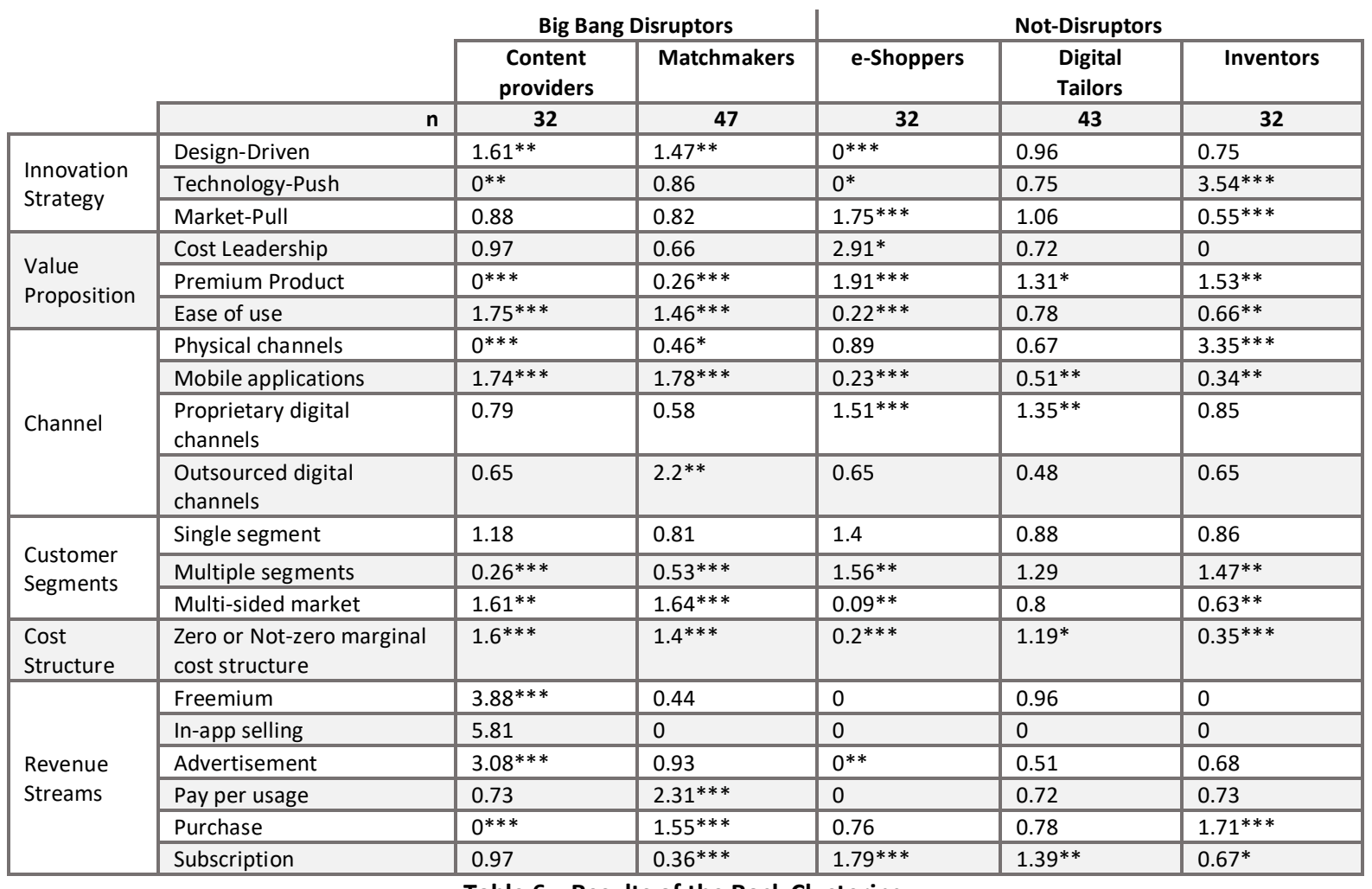

Table 6 - Results of the Rock Clustering

Regarding the Innovation Strategy building block, BBDs present an overpopulation in the design-driven innovation strategy, differently from the NDs where the other two strategies are delineated. Also, the market-pull strategy is consistently present in the two disruptors' clusters being the most represented strategy in the dataset (about 58\%), but its presence is lower, as the lift show, than in the whole dataset. A remarkable concentration of technologypush solutions characterizes the third NDs clusters.

Considering the value proposition variable, the two BBDs clusters differentiate from the rest with a neat Ease of Use proposition. Indeed, since the disruptors prior classification, they are characterized by a non-classic Porter positioning which is in line with this result. Nondisruptors present premium value proposition majorly and, in the minority, a cost leadership value proposition.

Looking at the channels, BBDs separate among app-driven solution and outsourced digital solution, proper of marketplaces and e-commerce. The difference with NDs is still evident. These latter adopt a proprietary digital channel or a retail distribution. We can denote how a retail channel is combined with a technology-push solution in the third cluster. 
BBDs are uniform regarding the customer segmentation, since being a multi-sided business is an essential characteristic. Instead, NDs usually rely on multiple segmentation.

Zero-cost structure organizations are prevalent in the BBDs clusters. Nonetheless, both disruptors' clusters show a robust zero-cost structure representation, significantly higher than the average population. This was, indeed, one of the conditions shared by 74 disruptors out of 79 of the database (the one respecting rules 1,2, and 3). This element also characterizes one of the NDs clusters.

In the end, regarding the revenues streams, the situation is more complex. Different models can be recognized as significantly more present in the disruptors' clusters: advertising, payper-usage, freemium and purchase. Notwithstanding their over-representation, the in-app revenue model is consistently present. The issue with in-app selling is the low global representativeness of this revenue model in the database which ostracizes its statistical significance. From the side of NDs, subscription (present in two clusters) and purchase are the most represented and significant revenue streams. This latter is consistent with the other results of the same cluster which shows the physical delivery of a premium, high-end, technological product.

\section{Discussion}

As previously mentioned, this research aims to identify the decisions on the design variables of a business model which may lead to the creation of a Big Bang Disruptor. Therefore, we critically analyze the results of the clustering analysis on the Unicorn's sample, divided between BBDs and NDs. The discussion is going to be based on the main dimensions defined in the conceptual framework.

Table 7 summarizes the representative characteristics for each cluster, highlighting a symbolic case for each one.

First of all, it is important to stress how these pieces of evidence are not pointing at the best decision on a design variable in the business model. The entire sample, both BBDs, and NDs are companies able to convince the investors, being Unicorns successfully. What these results point out is the relevance of some design variables to have a disruptive impact on the market. In this perspective, we want to stress how these are all successful companies (De Massis et al., 2016), despite being or not BBDs, indeed we are aiming to define common characteristics 
among BBDs, and how they differ from other successful companies which do not have the BBD characteristics (Downes and Nunes, 2014).

\begin{tabular}{|c|c|c|c|c|c|}
\hline & \multicolumn{2}{|c|}{ Big Bang Disruptors } & \multicolumn{3}{|c|}{ Not-Disruptors } \\
\hline & $\begin{array}{l}\text { Content } \\
\text { providers }\end{array}$ & Matchmakers & e-Shoppers & Digital Tailors & Inventors \\
\hline $\begin{array}{c}\text { Innovation } \\
\text { Strategy }\end{array}$ & Design-Driven & Design-Driven & Market-Pull & Market-Pull & $\begin{array}{c}\text { Technology- } \\
\text { Push }\end{array}$ \\
\hline $\begin{array}{c}\text { Value } \\
\text { Proposition }\end{array}$ & Ease of Use & Ease of Use & $\begin{array}{c}\text { Premium } \\
\text { Cost } \\
\text { Leadership }\end{array}$ & Premium & Premium \\
\hline Channel & Mobile Apps & $\begin{array}{c}\text { Mobile Apps } \\
\text { Outsourced } \\
\text { digital }\end{array}$ & $\begin{array}{l}\text { Proprietary } \\
\text { Digital }\end{array}$ & $\begin{array}{l}\text { Proprietary } \\
\text { Digital }\end{array}$ & Retail \\
\hline Segments & Multi-sided & Multi-sided & $\begin{array}{l}\text { Multiple } \\
\text { Segments }\end{array}$ & $\begin{array}{l}\text { Multiple } \\
\text { Segments }\end{array}$ & $\begin{array}{l}\text { Multiple } \\
\text { Segments }\end{array}$ \\
\hline Cost Structure & Zero & Zero & Non-zero & Zero & Non-zero \\
\hline $\begin{array}{l}\text { Revenue } \\
\text { Stream }\end{array}$ & $\begin{array}{c}\text { Freemium } \\
\text { Advertisement }\end{array}$ & $\begin{array}{c}\text { Purchase } \\
\text { Pay-per-usage }\end{array}$ & Subscription & Subscription & Purchase \\
\hline Example & Spotify & Airbnb & $\begin{array}{l}\text { The Honest } \\
\text { Company }\end{array}$ & Cloudera & DJI \\
\hline
\end{tabular}

Table 7-Representative characteristics and cases for each cluster

Before entering in the details discussion of the design variables that characterize the different clusters, we would like to discuss the link between the defining characteristics of BBDs that defined the rules, and the clusters and those characteristics which are common among BBDs and NDs.

The defining characteristics of Big Bang Disruption let emerge four rules and four necessary conditions (Table 4). It is interesting to see how technology play a key role among the necessary conditions, even though technological innovation is a common strategy among NDs. This seems to let emerge a different role of technologies, which act as an enabler of systems, more than being the heart of the innovation process (Adner and Kapoor, 2016).

The negligible switching costs seem not to have a direct link among the design variables of the business model that emerged in the following analyses. On the contrary, the absence of a classical Poter positioning and the absence of customer segments seem to be coherent with the relevance of the Ease of use among the disruptors, as well as the diffusion of multiple segmentations among NDs.

Among numerous differences, which are going to be further detailed in the next sections, there are some characteristics which seem to describe both some BBDs and NDs: the coststructure and the Revenue Streams. Indeed, in both cases the most common implementation of these building blocks among the two clusters of BBDs can also be found in at least one 
cluster of NDs, making them not distinctive characteristics. This seem coherent with Big Bang Disruption as an innovation strategy, rather than an operationalization of an innovation into a solution (Downes and Nunes, 2014).

\subsection{Big Bang Disruptors as Innovators of Meanings}

Regarding the innovation strategy of BBDs, based on the interaction between Problem and Solution, we are dealing with strategies based on the fact that "[disruptors] don't share your [the incumbents'] approach to solving customer needs" (Downes and Nunes, 2014). Our empirical results fully support this statements. Therefore, the innovation strategy significantly adopted by disruptors is the so-called design-driven strategy which consists in the innovation of the meaning: aiming to change the reason why people use and love a product or a service, instead of improving functionalities relying on market analysis or technological innovation (Verganti, 2009).

The starting point of this innovation strategy is the key difference with traditional approaches. Technology itself is not the center of innovation, as it was the case for Christensen and Rosenbloom (1995) and Chesbrough (2003), but it is more considered as an enabler (e.g., Buganza et al., 2015, Dell'Era et al., 2017). Market needs' analysis (e.g., Von Hippel, 1986), as well, is not enough to propose an innovation in the meaning domain, bringing more to incremental innovations of what is already present on the market (Verganti, 2009). These results are coherent with the latest evolution of the Design-Driven Innovation model; indeed according to Verganti (2017), we are now living in an overcrowded world, awash with ideas. In other words, it is not difficult - anymore - to generate ideas to foster innovation, while it is still challenging and perhaps more relevant to define a meaningful vision to be followed, having an impact to the reason why people use a product or a service.

A clear example of this may be Airbnb, which has seen its business model taking off when the mission of the company become "Belong anywhere", proposing users' to use their booking services, instead of other digital platforms that rely on hotels and professional providers, to have the chance to feel a "local" experience all over the world, feeling at home (Gallagher, 2017). Similarly, also Spotify - representative of the first cluster - leverage innovation of meaning and has been studied in that perspective (Trabucchi et al., 2017a). 
Regarding the ND,s the results are coherent with the definitions of the two strategies. Technology-push innovation (e.g., Anderson and Tushman, 1990; Tushman et al., 1997) can lead to excellent results, but at the same time its development process is long and complicated going through different stages before setting a dominant design (e.g., Tushman et al., 1997), as the JDI case - working in the drone industry - can show. The technology is promising and driving innovation, but companies are still searching for the solution that can significantly take the market. Regarding the market-pull structure, once again the fact that it does not lead to a disruptive impact on the market is coherent with previous researches that claim that it is more suitable for incremental innovations (e.g., Verganti, 2009).

Coherently with the innovation strategy, both the BBDs clusters share a value proposition based on the ease-of-use. It is not a traditional Porter's strategy, leveraging on the simplicity, usability and customer immediacy of the solution as the main value for the customer (AlMomani et al., 2009; Khare et al., 2016). Furthermore, ease of use has also been highlighted by Hamel (1996) as the main driver of the future strategy focus and by March (1994) as a new dimension in product design. The importance of this factor is not merely industrial or economic, but it is psychologically rooted. Indeed, Schwartz (2004) - considering the paradox of choice - remarks how the augmenting choice criteria and offering width increase the anxiety during product selection with a deterrent effect towards shopping.

Looking at the NDs clusters, they are all based on traditional innovation strategies, i.e., market pull or technology push) and more traditional value proposition, i.e., premium, cost leadership), still successful, but with a less disruptive impact on the market.

\subsection{Big Bang Disruptors as fast-growing platforms}

Big Bang Disruption is - by definition -characterized by an exponentially fast growth (Downes \& Nunes, 2014), this is coherent with the kind of channels mainly adopted by disruptors: apps and outsourced digital channels. Both of them enhance the chance of a fast and pervasive diffusion, leveraging network effects built by other providers (Gawer and Cusumano, 2014), such as Apple, Google or Amazon.

The customer segments offer another relevant insight. Both BBDs clusters share a multi-sided market segmentation, meaning that they address two or more set of customers with a specific value proposition and match them (Rochet and Tirole, 2003; Muzellec et al., 2015; Trabucchi 
et al., 2017b). Two representative cases, for regarding the BBDs clusters, are Spotify and Airbnb that bring together end-users on one side and artists and host on the second side. According to Evans (2009) and Eisenmann et al. (2006), multi-sided platforms enable the reduction of transaction costs by increasing return scale (Eisenmann et al., 2006) and internalizing externalities (Evans, 2009). The reduction of transaction costs is strictly related to an enhanced diffusion and adoption of the solution, since it is linked to a more optimal economic state (Gawer, 2009). This market structure can be directly linked with the diffusion process. According to the Bass (1969) model of innovation and the following extended models, also presented by Cantamessa and Montagna (2016), non-multi-sided solution, which we will call single-sided, rely on an imitative diffusion process (Bass, 1969; Cantamessa and Montagna, 2016). Multi-sided platforms, on the other hand, rely on a so-called imitativereciprocal process (Cantamessa and Montagna, 2016). In this case, the rapidity of diffusion depends on the number of users on the other sides since the different segments of customers are interrelated. The robustness of this finding can be further explored. Indeed, the more rapid diffusion can also be tested on the Unicorns' dataset by measuring the number of years elapsed between the foundation of each company and its inclusion in the unicorns' list as proxy: this measure is also known as time to market cap (TTMC) (Ramadan et al., 2015). BBDs have an average TTMC of 5.86 years while NDs have an average of 8 years, with an acceptable 0,73 likelihood ratio test (Han et al., 2012). It is proved that the TTMC of disruptors is significantly lower than the one of non-disruptors.

This common characteristics among the two clusters seem to be coherent with recent contribution coming from the research stream on platforms (e.g., Libert et al., 2016). In particular, recent contributions shows how platform mechanisms and evolutions among platform providers and complementors may lead to significative changes in the competitive scenario (Legrand et al., 2017; Pellizzoni et al., 2018).

The faster diffusion of BBDs is also enhanced by the findings on the cost structure. Therefore, the Zero-cost structure is found as an important antecedent of disruption. A zero-marginalcost structure, as introduced by Rifkin (2014), has an important, probably the highest, impact on scalability. Indeed, this type of cost structure nullifies the cost of offering the solution to a fast-growing number of users (Rifkin, 2014).

On the other hand, NDs, usually leverages on multiple segments, often through a differentiation strategy and may or may not have a zero-cost structure. The two 
representative companies showed in Table 5 match these possibilities. On the one hand, we have The Honest Company, based on a traditional cost structure offering a different kind of consumer goods to different targets, leveraging the concept of ethical consumerism. On the other hand, Cloudera relies on a zero-marginal-cost structure, offering software which is suitable for different market segments due to their large offer.

In the end, the revenue streams differentiate the two clusters of BBDs. On the one hand, some companies are mainly based on advertising or freemium models, coherently with the growing trend of offering services for free (Trabucchi et al., 2017b). On the other, the payper-usage and the eventually the purchase of the access is typical of multi-sided platforms (Rochet and Tirole, 2003; 2006; Rysman, 2009).

NDs leverage more traditional revenues streams, being based on the typical purchase or subscription models.

\section{Conclusion}

This paper leverages the concept of Big Bang Disruption with the aim to understand the design variable of a Business Model that may lead to this kind of innovation.

To reach the goal preliminary analyses are needed, defining rules to distinguish a Big Bang Disruptors from a Failed-to-Be-Big Bang Disruptors through csQCA (Ganter \& Hecker, 2014). Once the rules have been defined, they have been applied to the Unicorns' list defining a sample of BBDs and a sample of NDs. The two sets have been analyzed according to the developed conceptual framework. It is based on the Lean Canvas (Maurya, 2012), highlighting the primary design variables that can help in defining each building blocks. Through a ROCK clustering method (Muhlenbach and Lallich, 2009), five clusters that contain common pattern regarding design variables have been identified, two for BBDs and three for NDs.

From a theoretical perspective, this research has three main contributions. First, the developed conceptual framework offers the chance to leverage the Lean Canvas (Maurya, 2012) for further research, using it as a tool of analysis for innovative companies.

Moreover, it provides a link between the innovation of meaning and its impact on the market. Research so far focused mainly on the characteristics of this kind of innovation (e.g., Verganti, $2008,2009,2011$ ) and on the process to develop it (e.g., Buganza et al., 2015; Verganti, 2016, 
2017). This study confirms that the radicalness of this innovation strategy may lead to a disruptive impact on the market.

Finally, the literature on Two-Sided Markets and Multi-Sided Markets (e.g., Rochet and Tirole, 2003, 2006; Evans, 2003; Rysman, 2009) expanded significantly over the last years from a management perspective (e.g., Muzellec et al., 2015; Dou et al., 2016; Trabucchi et al. 2017b) showing the potentialities and the opportunities on this market structure. This study links this market structure with the concept of disruption, confirming models that treats this kind of businesses as a revolution in the market (e.g., Trabucchi et al. 2017b).

This study, of course, has limitations that may be overcome with further developments. First of all, the chance to leverage the Unicorns' sample has been useful to consider successful companies also in the control group (NDs), but at the same time, it introduces a bias. Indeed, all the considered companies have been positively evaluated by investors. Re-proposing a similar approach in different settings may increase the validity of the results. Moreover, the need to create defining rules for BBDs brought to a double effort in data gathering, a confirmatory panel of expert has confirmed the validity of the final database, but further research is needed to corroborate the results.

Finally, more emphasis should be posed upon the operational resources, activities, and partnerships which could precede a disruption. Indeed, this research focused on the strategic dimensions highlighted by the Lean Canvas, without considering other building blocks presented in the Business Model Canvas. Further research to explore the role of partnerships and resources may be interesting. Also, the confirmation of these findings through qualitative research, that may dig into the relationships between the different design variables could be relevant. Disruptors have to be foreseen, preferably considering case-dependent features and infrastructures and, then, adopt a qualitative approach.

\section{References}

Adner, R., \& Kapoor, R. (2016). Right Tech, Wrong Time. Harvard Business Review, 94(11), 60-67.

Adrodegari, F., Saccani, N., Kowalkowski, C., \& Vilo, J. (2017). PSS business model conceptualization and application. Production Planning \& Control, 28(15), 1251-1263.

Afuah, A., \& Tucci, C. L. (2001). Internet business models and strategies McGraw-Hill New York. 
Al-Momani, K., \& Noor, N. A. M. (2009). E-service quality, ease of use, usability and enjoyment as antecedents of e-CRM performance: An empirical investigation in Jordan mobile phone services. The Asian Journal of Technology Management, 2(2), 50-63.

Anderson, P., \& Tushman, M. L. (1990). Technological discontinuities and dominant designs: A cyclical model of technological change. Administrative Science Quarterly, 604-633.

Applegate, L. M. (2001). Emerging networked business models: Lessons from the field Harvard Business School Case Services.

Baker, S. (2013). 5 key metrics for your lean startup. Shane Baker Blog, 2017. doi:https://shanebarker.com/blog/5-key-metrics-for-your-lean-startup/

Bass, F. M. (1969). A new product growth for model consumer durables. Management Science, 15(5), $215-227$. Battistella, C., De Toni, A. F., De Zan, G., \& Pessot, E. (2017). Cultivating business model agility through focused capabilities: A multiple case study. Journal of Business Research, 73, 65-82. doi:10.1016/j.jbusres.2016.12.007

Bertels, H. M., Koen, P. A., \& Elsum, I. (2015). Business models outside the core: Lessons learned from success and failure. Research-Technology Management, 58(2), 20-29.

Bharadwaj, A., El Sawy, O. A., Pavlou, P. A., \& Venkatraman, N. (2013). Digital business strategy: Toward a next generation of insights. MIS Quarterly, 37(2), 471-482.

Björkdahl, J. (2009). Technology cross-fertilization and the business model: The case of integrating ICTs in mechanical engineering products. Research Policy, 38(9), 1468-1477.

Bontis, N. (2001). Assessing knowledge assets: A review of the models used to measure intellectual capital. International Journal of Management Reviews, 3(1), 41-60.

Buganza, T., Dell'Era, C., Pellizzoni, E., Trabucchi, D., \& Verganti, R. (2015). Unveiling the potentialities provided by new technologies: A process to pursue technology epiphanies in the smartphone app industry. Creativity and Innovation Management, 24(3), 391-414.

Cantamessa, M., \& Montagna, F. (2016). Management of innovation and product development. Springer,

Casadesus-Masanell, R., \& Ricart, J. E. (2010). From strategy to business models and onto tactics. Long Range Planning, 43(2), 195-215.

CB Insights.The complete list of unicorn companies. Retrieved from https://www.cbinsights.com/researchunicorn-companies

Chesbrough, H. W. (2003). Open innovation: The new imperative for creating and profiting from technology Harvard Business Press.

Chesbrough, H., \& Rosenbloom, R. S. (2002). The role of the business model in capturing value from innovation: Evidence fromXeroxxCorporation'ss technology spin-off companies. Industrial and Corporate Change, 11(3), 529-555.

Chesbrough, H. (2010). Business Model Innovation: Opportunities and Barriers. Long Range Planning 43 (2-3): 354-363.

Christensen, C. M. (1997). The innovator's dilemma: When new technologies cause great firms to fail Harvard Business Review Press. 
Christensen, C. M. (2001). The past and future of competitive advantage. MIT Sloan Management Review, 42(2), 105.

Christensen, C. M., Raynor, M., \& McDonald, R. (2015). What is disruptive innovation? Harvard Business Review

Cosenz, F. (2017). Supporting start-up business model design through system dynamics modelling. Management Decision, 55(1), 57-80.

Daly, P. (2017). Business apprenticeship: A viable business model in management education. Journal of Management Development, 36(6)

Dell'Era, C., Altuna, N., Magistretti, S., \& Verganti, R. (2017). Discovering quiescent meanings in technologies: Exploring the design management practices that support the development of technology epiphanies. Technology Analysis \& Strategic Management, 29(2), 149-166.

Doganova, L., \& Eyquem-Renault, M. (2009). What do business models do?: Innovation devices in technology entrepreneurship. Research Policy, 38(10), 1559-1570.

Dou, G., He, P., \& Xu, X. (2016). One-side value-added service investment and pricing strategies for a two-sided platform. International Journal of Production Research, 54(13), 3808-3821. doi:10.1080/00207543.2016.1148275

Downes, L., \& Nunes, P. (2013). Big bang disruption. Harvard Business Review, (2), 44-56.

Downes, L., \& Nunes, P. (2014). Big bang disruption: Strategy in the age of devastating innovation Penguin.

Downes, L., Mui, C., \& Negroponte, N. (2000). Unleashing the killer app: Digital strategies for market dominance. Boston: (Harvard Business School Press.

Duşa, A. (2007). User manual for the QCA (GUI) package in R. Journal of Business Research, 60(5), 576-586.

Dutta, M., Mahanta, A. K., \& Pujari, A. K. (2005). QROCK: A quick version of the ROCK algorithm for clustering of categorical data. Pattern Recognition Letters, 26(15), 2364-2373.

Eisenmann, T., Parker, G., \& Van Alstyne, M. W. (2006). Strategies for two-sided markets. Harvard Business Review, 84(10)

Evans, D. S. (2003). The antitrust economics of multi-sided platform markets. Yale Journal on Regulation, 20(2), 325-381.

Foss, N. J. \& Saebi, T. (2017). Fifteen Years of Research on Business Model Innovation: How Far have we Come, and Where should we Go? Journal of Management 43 (1): 200-227.

Gallagher, L. (2017).the Airbnbb story (first edit).

Ganter, A., \& Hecker, A. (2014). Configurational paths to organizational innovation: Qualitative comparative analyses of antecedents and contingencies. Journal of Business Research, 67(6), 1285-1292.

Gawer, A. (2009). Platform dynamics and strategies: From products to services. Platforms, market, and innovation (pp. 45-76)

Gawer, A., \& Cusumano, M. A. (2014). Industry platforms and ecosystem innovation. Journal of Product Innovation Management, 31(3), 417-433. doi:10.1111/jpim.12105

Ghezzi, A. \& Cavallo, A. (2018). Agile Business Model Innovation in Digital Entrepreneurship: Lean Startup Approaches. Journal of Business Research. 
Ghezzi, A., Rangone, A. \& Balocco, R. (2013). Technology Diffusion Theory Revisited: A Regulation, Environment, Strategy, Technology Model for Technology Activation Analysis of Mobile ICT. Technology Analysis \& Strategic Management 25 (10): 1223-1249.

Ghezzi, A., Cortimiglia, M. \& Frank, A. (2015). Strategy and Business Model Design in Dynamic Telecommunications Industries: A Study on Italian Mobile Network Operators. Technological Forecasting and Social Change 90: 346-354.

Guha, S., Rastogi, R., \& Shim, K. (1999). ROCK: A robust clustering algorithm for categorical attributes. Paper presented at the Data Engineering, 1999. Proceedings., 15th International Conference on, 512-521.

Hagiu, A. (2009). Multi-sided platforms: From microfoundations to design and expansion strategies. Harvard Business School, 1-25. doi:doi:10.2139/ssrn.955584

Hamel, G. (1996). Strategy as revolution Harvard Business Review.

Hamel, G., \& Ruben, P. (2000). Leading the revolution Harvard Business School Press Boston, MA.

Han, G., Schell, M. J., \& Kim, J. (2012). Comparing two exponential distributions using the exact likelihood ratio test. Statistics in Biopharmaceutical Research, 4(4), 348-356.

Hastie, T., Tibshirani, R., \& Friedman, J. (2009). Overview of supervised learning. The elements of statistical learning (pp. 9-41) Springer.

Hathaway, I. (2016). What startup accelerators really do. Harvard Business Review, 1

Hellofs, L. L., \& Jacobson, R. (1999). Market share and customers' perceptions of quality: When can firms grow their way to higher versus lower quality? The Journal of Marketing, 16-25.

Herrmann, A., Gassmann, O., \& Eisert, U. (2007). An empirical study of the antecedents for radical product innovations and capabilities for transformation. Journal of Engineering and Technology Management, 24(1), 92-120.

Karimi, J., \& Walter, Z. (2015). The role of dynamic capabilities in responding to digital disruption: A factorbased study of the newspaper industry. Journal of Management Information Systems, 32(1), 39-81.

Katz, M. L., \& Shapiro, C. (1985). Network externalities, competition, and compatibility. The American Economic Review, 75(3), 424-440.

Kazan, E., Tan, C., \& Lim, E. T. (2014). Towards a framework of digital platform disruption: A comparative study of centralized \& decentralized digital payment providers. Paper presented at the

Khare, A., Stewart, B., \& Schatz, R. (2016). Phantomex Machinaa: Digital disruption's role in business model transformation Springer.

Kilkki, K., Mäntylä, M., Karhu, K., Hämmäinen, H., \& Ailisto, H. (2018). A disruption framework. Technological Forecasting and Social Change, 129, 275-284.

Kim, E., Nam, D., \& Stimpert, J. (2004). Testing the applicability ofPorter'ss generic strategies in the digital age: A studyof Koreann cyber malls. Journal of Business Strategies, 21(1), 19.

Kobus, J. (2016). Demystifying lean IT: Conceptualization and definition. MKWI 2016 Proceedings,

Kostoff, R. N., Boylan, R., \& Simons, G. R. (2004). Disruptive technology roadmaps. Technological Forecasting and Social Change, 71(1-2), 141-159. 
Kulins, C., Leonardy, H., \& Weber, C. (2016). A configurational approach in business model design. Journal of Business Research, 69(4), 1437-1441. doi:10.1016/j.jbusres.2015.10.121

Kurzweil, R. (2005). The singularity is near: When humans transcend biology Penguin.

Legrand, J., Le Masson, P. Thomas, M. and Weil, B. (2017). Rise and Fall of Platforms: Systematic Analysis of Platform Dynamics Thanks to Axiomatic Design. International Conference on Engineering Design, Vancouver, Canada.

Libert, B., Beck, M., \& Wind, J. (2016). The network imperative: How to survive and grow in the age of digital business models Harvard Business Press Review.

Madhok, A. (2002). Reassessing the fundamentals and beyond: Ronald Coase, the transaction cost and resource-based theories of the firm and the institutional structure of production. Strategic Management Journal, 23(6), 535-550.

Magistretti, S. \& Dell'Era, C. (2018). Unveiling Opportunities Afforded by Emerging Technologies: Evidences from the Drone Industry. Technology Analysis \& Strategic Management: 1-18. https://doi.org/10.1080/09537325.2018.1538497

Maidique, M. A., \& Zirger, B. J. (1984). A study of success and failure in product innovation: The case of the US electronics industry. IEEE Transactions on Engineering Management, (4), 192-203.

March, A. (1994). Usability: The new dimension of product design. Harvard Business Review, 72(5), 144-149.

Massa, L., Tucci, C., \& Afuah, A. (2017). A critical assessment of business model research. Academy of Management Annals, 11(1), 73-104.

Massis, D., Vittorio, A., Frattini, F., \& Quillico, F. (2016). What big companies can learn from the success of the unicorns. Harvard Business Review,

Maurya, A. (2012). Running Leann: Iterate from plan A to a plan that works " O'Reilly Media, Inc.".

Miller, D. (1988). Relating porter's business strategies to environment and structure: Analysis and performance implications. Academy of Management Journal, 31(2), 280-308.

Mitchell, D. \& Coles, C. (2003). The Ultimate Competitive Advantage of Continuing Business Model Innovation. Journal of Business Strategy 24 (5): 15-21.

Mizik, N., \& Jacobson, R. (2003). Trading off between value creation and value appropriation: The financial implications of shifts in strategic emphasis. Journal of Marketing, 67(1), 63-76.

Muhlenbach, F., \& Lallich, S. (2009). A new clustering algorithm based on regions of influence with selfdetection of the best number of clusters. Paper presented at the Data Mining, 2009. ICDM'09. Ninth IEEE International Conference on, 884-889.

Muzellec, L., Ronteau, S., \& Lambkin, M. (2015). Two-sided internet platforms: A business model lifecycle perspective. Industrial Marketing Management, 45, 139-150.

Nielsen, K., \& Brun $\varnothing$, T. D. (2014). Mass customisation assessment and measurement framework. Enabling manufacturing competitiveness and economic sustainability (pp. 165-170) Springer.

Osterwalder, A, Pigneur, Y. Bernarda, G. \& Smith, A. (2014). Value Proposition Design: How to Create Products and Services Customers Want John Wiley \& Sons, 2014. 
Osterwalder, A., \& Pigneur, Y. (2010). Business model generation: A handbook for visionaries, game changers, and challengers John Wiley \& Sons.

Pellizzoni, E., Trabucchi, D., \& Buganza, T. (2018). Platform strategies: how the position in the network drives success. Technology Analysis \& Strategic Management, 1-14.

Pigneur, Y. \& Werthner, H. (2009). Design and Management of Business Models and Processes in Service Science. Information Systems and e-Business Management 7 (2): 119-121.

Porter, M. E. (1980). Techniques for analyzing industries and competitors. Competitive Strategy. New York: Free,

Porter, M. E. (2001). Strategy and the internet. Harvard Business Review, 79(3), 62-78.

Ragin, C. C. (2006). Set relations in social research: Evaluating their consistency and coverage. Political Analysis, 14(3), 291-310.

Ragin, C. C. (2013). The comparative method: Moving beyond qualitative and quantitative strategies University of California Press.

Rayna, T., \& Striukova, L. (2016). 360 Business Model Innovation: Toward an Integrated View of Business Model Innovation. Research-Technology Management, 59(3), 21-28.

Rochet, J. -., \& Tirole, J. (2003). Platform competition in two-sided markets. Journal of the European Economic Association, 1(4), 990-1029. doi:10.1162/154247603322493212

Rochet, J. -., \& Tirole, J. (2006). Two-sided markets: A progress report. RAND Journal of Economics, 37(3), 645667.

Rogers, E. M. (2010). Diffusion of innovations Simon and Schuster.

Rumble, R., \& Mangematin, V. (2015). Business model implementation: The antecedents of multisidedness. Business models and modelling (pp. 97-131) Emerald Group Publishing Limited.

Sainio, L., \& Puumalainen, K. (2007). Evaluating technology disruptiveness in a strategic corporate context: A case study. Technological Forecasting and Social Change, 74(8), 1315-1333.

Schneckenberg, D., Velamuri, V. \& Comberg, C. (2018). The Design Logic of New Business Models: Unveiling Cognitive Foundations of Managerial Reasoning. European Management Review. https://doi.org/10.1111/emre.12293

Schneider, C. Q., \& Wagemann, C. (2010). Standards of good practice in qualitative comparative analysis (QCA) and fuzzy-sets. Comparative Sociology, 9(3), 397-418.

Schuelke-Leech, B. (2018). A model for understanding the orders of magnitude of disruptive technologies. Technological Forecasting and Social Change, 129, 261-274.

Schwartz, B. (2004). The paradox of choice: Why more is less. New York: Ecco.

Smailhodzic, E., Boonstra, A., \& Langley, D. (2016). Social media disruptive change in healthcare: Responses of healthcare providers? Paper presented at the Ecis, Research-in-ProgressPaper17.

Stewart, D. W., \& Zhao, Q. (2000). Internet marketing, business models, and public policy. Journal of Public Policy \& Marketing, 19(2), 287-296.

Storey, C., Cankurtaran, P., Papastathopoulou, P., \& Hultink, E. J. (2016). Success factors for service innovation: A meta-analysis. Journal of Product Innovation Management, 33(5), 527-548. 
Tadesse, M., \& Belay, K. (2004). Factors influencing adoption of soil conservation measures insouthern Ethiopiaa: The case of gununo area. Journal of Agriculture and Rural Development in the Tropics and Subtropics (JARTS), 105(1), 49-62.

Täuscher, K. and S. M. Laudien. (2018). Understanding Platform Business Models: A Mixed Methods Study of Marketplaces. European Management Journal36 (3): 319-329. doi:10.1016/j.emj.2017.06.005.

Teece, D. J. (2010). Business models, business strategy and innovation. Long Range Planning, 43(2), $172-194$.

Toro-Jarrín, M. A., Ponce-Jaramillo, I. E., \& Güemes-Castorena, D. (2016). Methodology for the of building process integration of business model canvas and technological roadmap. Technological Forecasting and Social Change, 110, 213-225.

Trabucchi, D., Buganza, T., \& Pellizzoni, E. (2017b). Give away your digital services: Leveraging big data to capture value Research-Technology Management, 60(2), 43-

52. https://doi.org/10.1080/08956308.2017.1276390

Trabucchi, D., Pellizzoni, E., Buganza, T., \& Verganti, R. (2017a). Interplay between technology and meaning: How music majors survived? Creativity and Innovation Management, 1-12. https://doi.org/10.1111/caim.12234

Trabucchi, D. \& Buganza, T. (2018). Data-Driven Innovation: Switching the Perspective on Big Data. European Journal of Innovation Management. https://doi.org/10.1108/EJIM-01-2018-0017

Treacy, M. (2005). Double-digit growth: How great companies achieve it--no matter what Penguin.

Treacy, M., \& Wiersema, F. (2007). The discipline of market leaders: Choose your customers, narrow your focus, dominate your market Basic Books.

Trimi, S. \& Berbegal-Mirabent, J. 2012. "Business Model Innovation in Entrepreneurship." International Entrepreneurship and Management Journal 8 (4): 449-465.

Tufféry, S. (2011). Data mining and statistics for decision making Wiley Chichester.

Tushman, M. L., Anderson, P. C., \& O’Reilly, C. (1997). Technology cycles, innovation streams, and ambidextrous organizations: Organization renewal through innovation streams and strategic change. Managing Strategic Innovation and Change, 34(3), 3-23.

Verganti, R. (2009)Design drivenn innovation: Changing the rules of competition by radically innovating what things mean Harvard Business Press.

Verganti, R. (2016). The innovative power of criticism. Harvard Business Review, 94(1-2), 88-95.

Verganti, R. (2017). Overcrowded: designing meaningful products in a world awash with ideas. Boston: MIT Press.

Von Hippel, E. (1986). Lead users: A source of novel product concepts. Management Science, 32(7), 791-805.

Zott, C., Amit, R., \& Massa, L. (2011). The business model: Recent developments and future research. Journal of Management, 37(4), 1019-1042.

Zott, C. \& Amit, R. (2007). Business Model Design and the Performance of Entrepreneurial Firms. Organization Science 18 (2): 181-199.

Zott, C. \& Amit, R. (2010). Business Model Design: An Activity System Perspective. Long Range Planning 43 (23): 216-226. 
Zott, C., Amit, R., \& Massa, L. (2011). The Business Model: Recent Developments and Future Research. Journal of Management 37 (4): 1019-1042.the rock

cluster 